\title{
Use of Finite-Difference Arrays of Observation Wells to Estimate Evapotranspiration From Ground Water in the Arkansas River Valley, Colorado
}

GEOLOGICAL SURVEY WATER-SUPPLY PAPER 2029-C

Prepared in cooperation with the U.S. Bureau of Reclamation, the Colorado Water Conservation Board, and the Southeastern Colorado Water Conservancy District

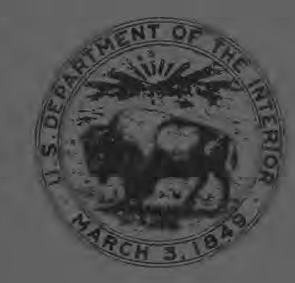




\section{Use of Finite-Difference Arrays of Observation Wells to Estimate Evapotranspiration From Ground Water in the Arkansas River Valley, Colorado}

By E. P. WEEKS and M. L. SOREY

CONTRIBUTIONS TO THE HYDROLOGY OF THE UNITED STATES

GEOLOGICAL SURVEY WATER-SUPPLY PAPER 2029-C

Prepared in cooperation with the U.S. Bureau of Reclamation, the Colorado Water Conservation Board, and the Southeastern Colorado Water Conservancy District

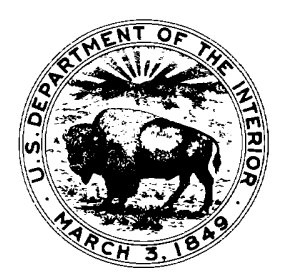




\section{UNITED STATES DEPARTMENT OF THE INTERIOR}

ROGERS C. B. MORTON, Secretary

\section{GEOLOGICAL SURVEY}

V. E. McKelvey, Director

Library of Congress catalog-card No. 73-600187

For sale by the Superintendent of Documents, U.S. Government Printing Office Washington, D.C. 20402 - Price 50 cents (paper cover)

Stock Number 2401-02451 


\section{CONTENTS}

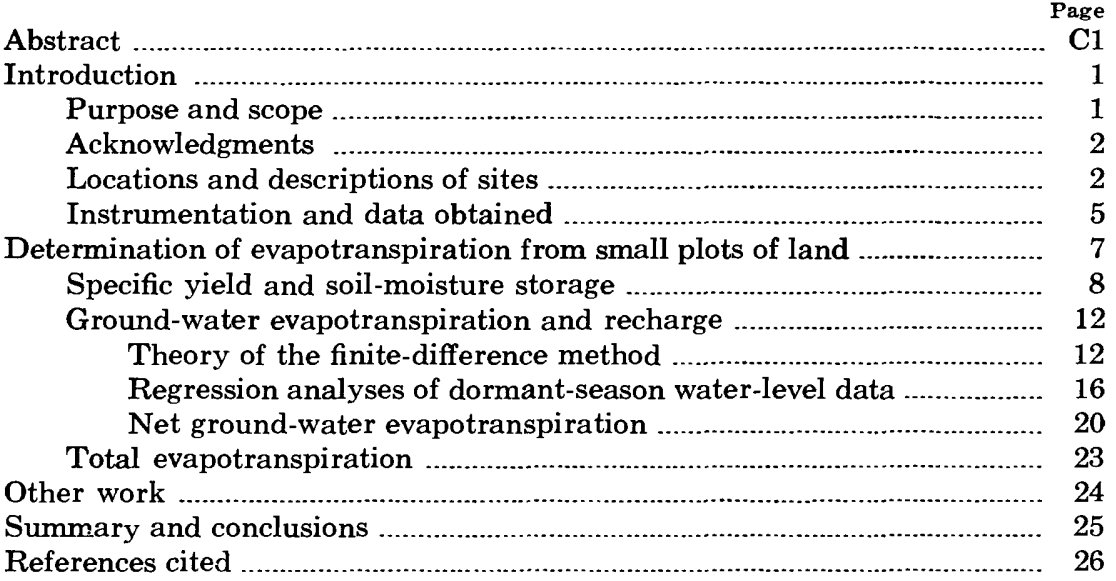

\section{ILLUSTRATIONS}

FIGURE 1. Map showing locations of study sites Page

2. Photographs showing density of vegetation and observation-well locations at Las Animas site and Lamar site

3. Map showing observation wells, land cover, and the river channel at the Lamar site

4. Soil-moisture logs for the Lamar site on two dates showing the specific yield determination

5. Diagrams showing basic data used in the finite-difference method

6. Plot of $f(h)$ versus $\Delta h / \Delta t$ for winter water-level data obtained at the Las Animas site

7. Plot of $f(h)$ versus $\Delta h / \Delta t$ for winter water-level data obtained at the Lamar site

8. Plot of $f(h)$ versus $\Delta h / \Delta t$ for summer water-level data obtained at the Las Animas site

\section{TABLES}

TABLE 1. Locations and physical characteristics of study 
TABLE 2. Water budgets for the Las Animas, Lamar, and Holly sites

3. Regression equations, correlation coefficients, standard errors of estimate, and comparisons of hydraulic conductivity estimates for the Las Animas and Lamar sites 


\title{
USE OF FINITE-DIFFERENCE ARRAYS OF OBSERVATION WELLS TO ESTIMATE EVAPOTRANSPIRATION FROM GROUND WATER IN THE ARKANSAS RIVER VALLEY, COLORADO
}

\author{
By E. P. WeEks and M. L. SOREY
}

\section{ABSTRACT}

A method to determine evapotranspiration from ground water was tested at four sites in the flood plain of the Arkansas River in Colorado. Approximate ground-water budgets were obtained by analyzing water-level data from observation wells installed in five-point arrays. The analyses were based on finitedifference approximations of the differential equation describing ground-water flow.

Data from the sites were divided into two groups by season. It was assumed that water levels during the dormant season were unaffected by evapotranspiration of ground water or by recharge, collectively termed "accretion." Regression analyses of these data were made to provide an equation for separating the effects of changes in aquifer storage and of aquifer heterogeneity from those due to accretion during the growing season. The data collected during the growing season were thus analyzed to determine accretion.

\section{INTRODUCTION}

\section{PURPOSE AND SCOPE}

This report describes the results of an investigation conducted by the U.S. Geological Survey to evaluate a technique proposed by Stallman $(1956,1967)$ to determine approximate ground-water budgets for small plots of land. The method should be useful to determine evapotranspiration from plots large enough to be representative of the field environment, but small enough to determine, for example, evapotranspiration from ground water for areas with specific types of plant cover or with water tables of different depths below land surface. The study included investigations at four sites in the flood plain of the Arkansas River in Colorado. A knowledge of evapotranspiration from 
ground water in the flood plain was needed to refine estimates of the effects of ground-water pumpage on streamflow and to evaluate the feasibility of augmenting streamflow by phreatophyte eradication or channel straightening.

\section{ACKNOWLEDGMENTS}

The study was made in cooperation with the U.S. Bureau of Reclamation, the Colorado Water Conservation Board, and the Southeastern Colorado Water Conservancy District. The study was conducted under the leadership of R. W. Stallman until October 1967, and by E. A. Sammel from October 1967 to September 1968.

The study was made possible by the cooperation of $\mathrm{H}$. H. Osburn, of Boone; D. M. Myers, of Las Animas; R. H. Nevius, of Lamar; and J. H. Whitehead, of Holly; all of whom allowed sites to be instrumented and operations to be continued on their land.

\section{LOCATIONS AND DESCRIPTIONS OF SITES}

Four sites with various types and densities of phreatophyte cover typical in the bottom land of the Arkansas River were selected to provide data on evapotranspiration from the ground-water reservoir. These sites, named for the nearby towns, are about 3 miles southeast of Boone, 3 miles west of Las Animas, 6 miles east of Lamar, and 2 miles east of Holly (fig. 1; table 1).

Phreatophytic vegetation consists of cottonwood trees at the Boone site, cottonwood trees and saltcedar at the Las Animas and Lamar sites, and salt grass at the Holly site. The general topography and the vegetation density at the Las Animas and Lamar sites are shown by aerial photographs (fig. 2). The land surface at these sites is typical of the flood plain of the Arkansas River and consists of numerous shallow channels interrupted and lined by hummocks developed by sedimentation around brush and other vegetation. Shallow closed depressions occur in the channels, and runoff and infiltration are quite nonuniform at the various sites. The Holly site is a salt grass pasture and has fewer channels and hummocks than the other sites. Infiltration at this site may be fairly uniform areally.

The nature, thickness, and uniformity of the aquifer materials, particularly in the zone of water-table fluctuations, have an important influence on the adequacy of the described method. These data were obtained from augered test holes at each observation well at all four sites. The test drilling indicated that the alluvial valley-fill deposits below a depth of about 5-10 feet from the land surface were fairly uniform in lithology, both within and among sites, and consisted of coarse sand and gravel. However, the materials at shallower depths varied significantly from site to site. At the Boone site, clay or silty 


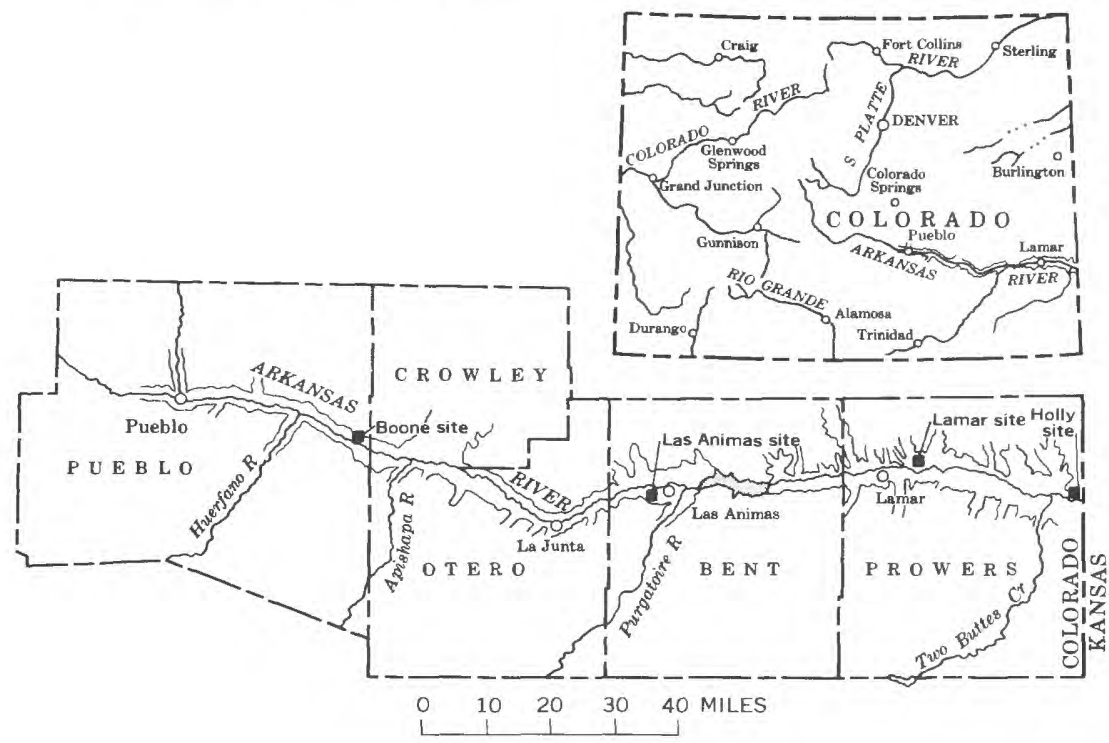

FIGURE 1.-Locations of sites where evapotranspiration from ground water in the Arkansas River valley in Colorado was estimated by finite-difference methods.

TABLE 1.-Locations and physical characteristics of study sites in the Arkansas River valley

\begin{tabular}{|c|c|c|c|c|c|}
\hline \multirow{2}{*}{ Site } & \multicolumn{2}{|r|}{ Location } & \multirow{2}{*}{ 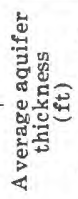 } & \multirow{2}{*}{ 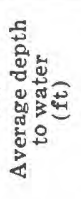 } & \multirow{2}{*}{ Vegetative cover } \\
\hline & County & $\begin{array}{l}\text { Section, township, } \\
\text { and range }\end{array}$ & & & \\
\hline Boone................ & Pueblo.............. & Sec. 15, T.21S., R.61W .... & 38 & 3.5 & Moderately dense cottonwood. \\
\hline Las Animas.. & Bent $\ldots \ldots$ & Sec. 5, T.23S., R.52W ... & 16 & 7 & $\begin{array}{l}\text { Moderately dense saltcedar } \\
\text { and cottonwood. }\end{array}$ \\
\hline Lamar............ & Prowers & Sec. 30, T.22S., R.45W .... & 55 & 6.5 & $\begin{array}{l}\text { Sparse saltcedar and } \\
\text { cottonwood. }\end{array}$ \\
\hline Holly $\ldots \ldots$ & do & Sec. 13, T.23S., R.42W .... & 45 & 5 & Sparse salt grass. \\
\hline
\end{tabular}

clay was found to depths of 5-10 feet below land surface. At the Las Animas site, silty sand occurred to a depth of 2-6 feet, overlying relatively clean sand. Material at the surface at the Lamar site consisted of $0-2$ feet of silty sand underlain by clean sand. At the Holly site, material at the surface included interbedded silt, clay, and sand extending to a depth of 5 or 6 feet. These general descriptions obtained from the test-hole cuttings were confirmed by examining drive samples from about 30 holes near one observation well at each site. 


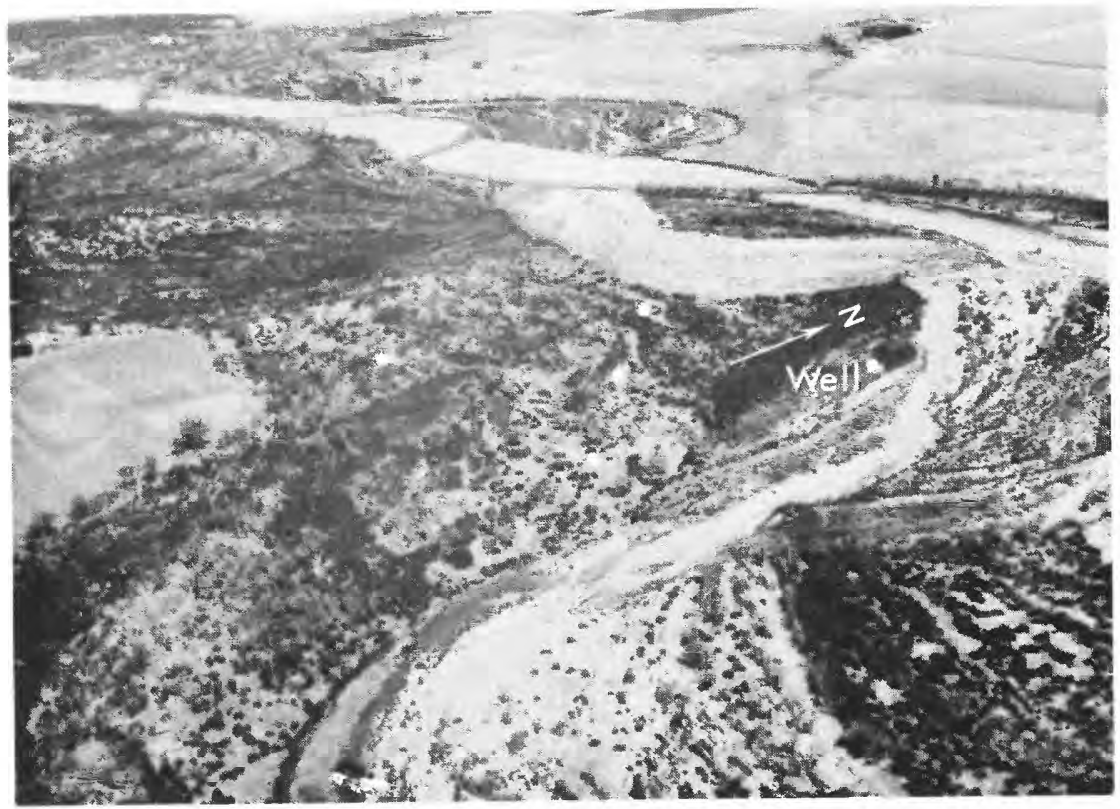

A

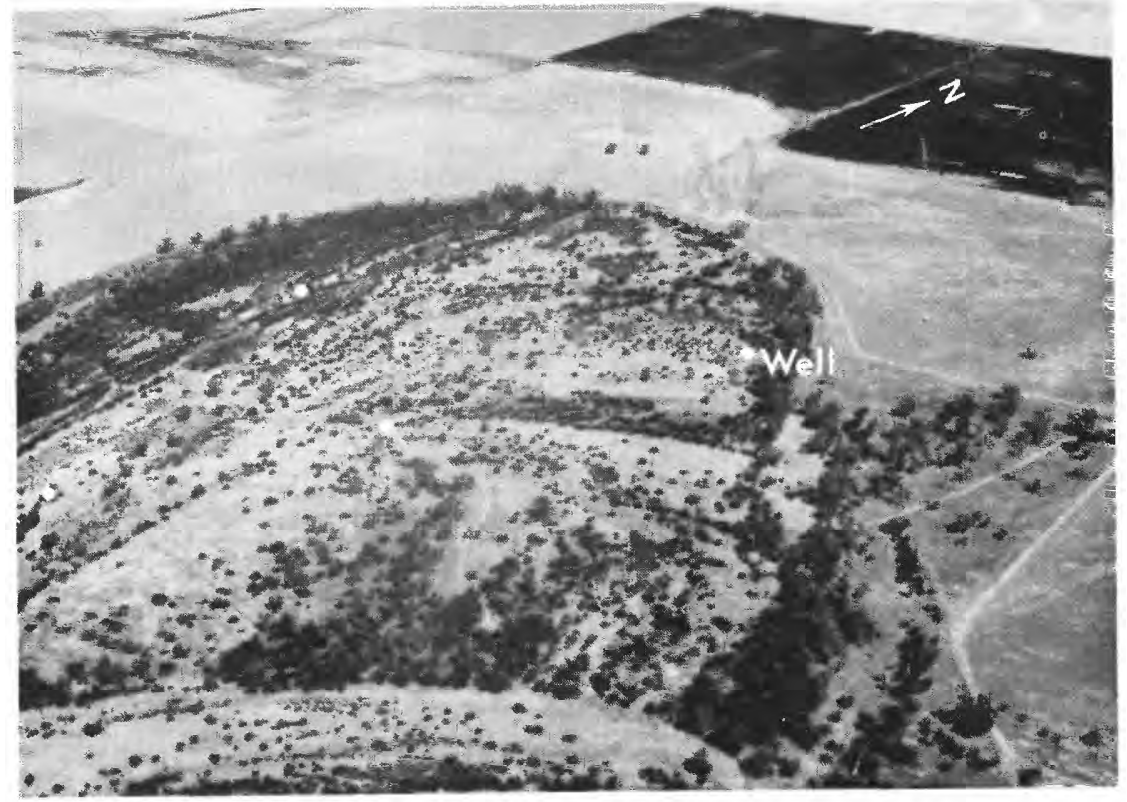

$B$

FIGURE 2.-Vegetative cover and observation-well locations. A, Las Animas site. Wells are spaced 600 feet from center well. $B$, Lamar site. Wells are spaced 707 feet from center well. Photographs by John E. Moore. 
Results of the test drilling (Major and others, 1970) indicate that the alluvial deposits are underlain by relatively impermeable bedrock, including shale at the Boone, Las Animas, and Holly sites, and sandstone and shale at the Lamar site. Ground-water flow in the bedrock was assumed negligible.

Depth to the water table, a significant control on the rate of evapotranspiration from ground water, was relatively constant within each array. Average depths to water below land surface during the 1965-69 period at the four sites, given in table 1, ranged from 3.5 feet at the Boone site to 7 feet at the Las Animas site.

The range in water-level fluctuation during any one year was less than 2 feet at the Boone site and less than 1.5 feet at the other sites. In general, short-term fluctuations were caused by changes in river stage. Long-term fluctuations were the result of recharge from adjacent irrigated areas and of drainage of ground water to the river. Water levels also rose occasionally in response to recharge from precipitation. In addition to the short- and long-term fluctuations, diurnal fluctuations in water level of as much as 0.05 foot were observed during the growing season. The fluctuations occurred because of diurnal changes in the rate of evapotranspiration from ground water.

\section{INSTRUMENTATION AND DATA OBTAINED}

Each of the four sites was instrumented to obtain a complete water budget. Ground-water inflow to, outflow from, and changes in groundwater storage within the site were estimated from continuous waterlevel records obtained in the five-well array. Changes in soil-moisture storage were estimated from neutron moisture logs made in an access tube near one observation well. Precipitation was measured by gages at the sites.

A typical observation-well array, that for the Lamar site, is shown in figure 3. Spacing of corner wells from the center well (dimension $a$ ) at the different sites ranged from 600 to 710 feet. These distances were made as large as possible to reduce errors resulting from waterlevel measurement accuracy of 0.01 foot (R. W. Stallman, written commun., 1968) but were small enough to include within the array relatively uniform vegetative cover and depth to water. The sites were also selected as far as feasible from the stream, pumped wells, and sources of surface-water recharge, such as unlined ditches or irrigated fields. The presence of such boundaries too near the site would result in short-term changes in water levels within the array that are not adequately described by the theory of the method.

All the observation wells but one used in the study were $11 / 4$ inches in diameter and were completed a few feet below the water table with 


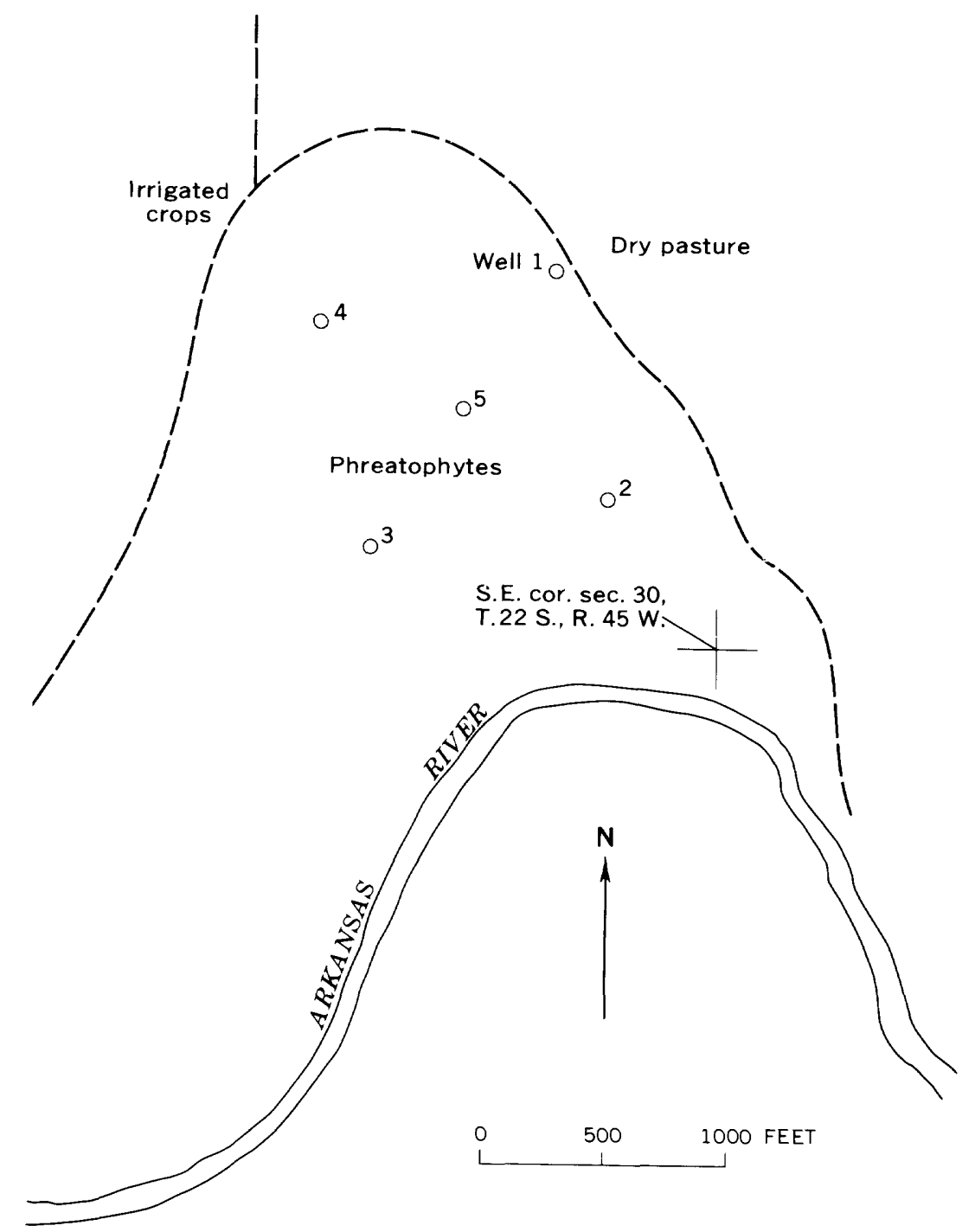

FIGURE 3.-Observation wells, land cover, and the river channel at the Lamar site.

2 -foot drive points. The center well in the Holly site array was an 18 -inch-diameter well screened to 46 feet, the base of the aquifer. Each of the small-diameter wells was equipped with an electronic water-level sensing device and digital recorder. The larger diameter well was equipped with a float-actuated digital recorder. 
Water-level records were obtained at the Boone site from 1965 through 1967, the Las Animas and Lamar sites from 1965 through 1969 , and at the Holly site from 1965 through 1968. However, waterlevel records were adequate for analysis by the finite-difference method only when they were complete for all five observation wells. Because of frequent failure of the electronic water-level sensing devices, adequate records were obtained only about one-third of the time. The records provided reasonably complete seasonal data on evapotranspiration for 1966 at the Las Animas and Lamar sites, for 1967 at the Holly site, and for 1968 at the Las Animas, Lamar, and Holly sites. Accurate altitudes of the measuring points of the observation wells, needed for the finite-difference analyses of the water levels, were obtained at each site by repeated precise leveling in 1965 , 1968 , and 1969.

About 40-50 soil-moisture logs were obtained with a neutron logger in an access tube installed near one of the observation wells at each site. The logs provided estimates of soil-moisture changes during the 1965-69 period and were also used to compute specific yield at each site. About 30-40 sets of soil samples were collected at each site to calibrate and check the neutron logs.

Precipitation was measured at each site from 1965 through 1967 with a tube-type gage containing oil to suppress evaporation. Annual precipitation computed from the gage measurements at each site was consistently lower than that for the nearby U.S. Weather Bureau station, suggesting that some evaporation did occur from the gages. For the summer munths, however, precipitation was so erratically distributed areally that the measurements at the sites were perhaps more reliable for the site than those at the remotely located U.S. Weather Bureau stations. In 1968, precipitation was measured by weighing rain gages. In 1969, no precipitation measurements were obtained, and so measurements at the nearby U.S. Weather Bureau stations were used for the water budgets.

\section{DETERMINATION OF EVAPOTRANSPIRATION FROM SMALL PLOTS OF LAND}

Analyses of the data obtained at each site included the determination of specific yield and changes in soil-moisture storage from the neutron logs, determination of net ground-water evapotranspiration by analysis of the water-level data, and determination of total evapotranspiration by summing decrease in soil moisture, net ground-water evapotranspiration, and precipitation. 


\section{SPECIFIC YIELD AND SOIL-MOISTURE STORAGE}

Both specific yield ${ }^{1}$ and changes in soil-moisture storage were determined from neutron moisture logs obtained periodically near one observation well at each site. The values of specific yield thus determined were used in conjunction with transmissivity estimates to check the finite-difference analysis and to determine transmissivity by the finite-difference method. Estimated monthly changes in soil moisture were used in conjunction with precipitation measurements and estimates of evapotranspiration from ground water to compute total evapotranspiration at each site.

The method used to determine specific yield is the same as that described by Meyer (1962) and Stallman (1967, p. 187). For the analyses, separate neutron logs were selected near the beginning and end of periods during which water levels persistently declined or rose. The change in moisture storage for the time span between logs was determined by integrating the difference in moisture content over the depth interval through which moisture changes due to waterlevel changes occurred (fig. 4). The change in moisture storage was divided by the change in water level during the period to obtain an estimate of specific yield.

Five values for specific yield determined at the Las Animas site ranged from 17 to 22 percent and averaged 18.6 percent. Nineteen values for specific yield determined at the Lamar site ranged from 17 to 25 percent and averaged 20.5 percent. Specific yield did not appear to differ significantly from summer to winter or between periods of rising and falling water table. Only three values for specific yield were determined for the Holly site: $0.0,2.6$, and 4.0 percent. Of these, the 2.6 percent value was considered the most reliable. However, the true specific yield could vary significantly from that value because of insufficient changes in moisture content for accurate determinations by this method and because of areal variations in soil texture within the site.

Changes in soil-moisture storage, needed to compute total evapotranspiration, were determined by integrating the part of the moisture logs extending from land surface to the approximate top of the capillary fringe. The integrations were made either by planimeter or by use of the trapezoidal rule. Changes in soil moisture were obtained from successive logs, obtained at approximately monthly intervals. The results are compiled in table 2.

Soil-moisture storage was quite high in January 1966 at all three sites because the June 1965 flood on the Arkansas River had satu-

\footnotetext{
${ }^{1}$ Specific yield of a rock or soil is the ratio of (1) the volume of water that the saturated rock or soil will yield by gravity to (2) its own volume. The definition implies that gravity drainage is complete.
} 


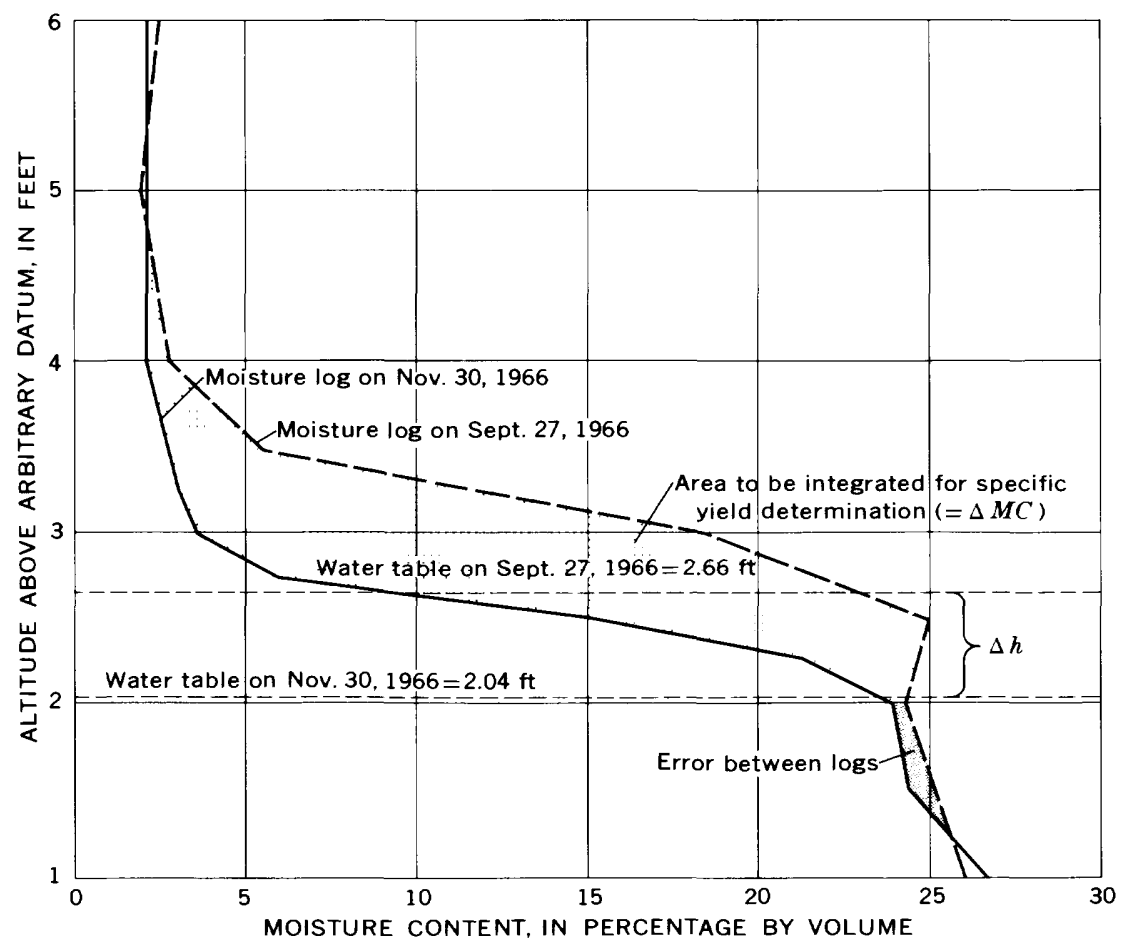

FIGURE 4.- Soil-moisture logs for the Lamar site on two dates showing a method for computing specific yield from changes in soil-moisture storage $(\triangle M C)$ and depth to the water table $(\Delta h)$. Specific yield equals $\Delta M C / \Delta h$.

rated the soil profile and subsequent rains in the summer and fall had prevented extreme soil-moisture depletion. At that time, more soil moisture was available for evapotranspiration from the fine soil at the Las Animas and Holly sites than from the sandy soil at the Lamar site. Consequently, soil-moisture depletion in 1966 at the former sites was much greater than at the Lamar site. In 1967 (results shown only for the Holly site) very little change in soil-moisture storage occurred, as soil moisture was already depleted to a low level, and was not replenished by the relatively small amount of precipitation that year.

Too few moisture logs were obtained in 1968 or 1969 to estimate changes in soil-moisture storage, but the relative size of such changes may be inferred from precipitation data. In 1968, a dry year, soilmoisture changes are presumed small, as in 1967. In 1969, however, precipitation was above normal and soil-moisture storage probably increased. Consequently, the total evapotranspiration values for 1969, described subsequently, probably are somewhat higher than those that would have been computed had moisture data been available. 


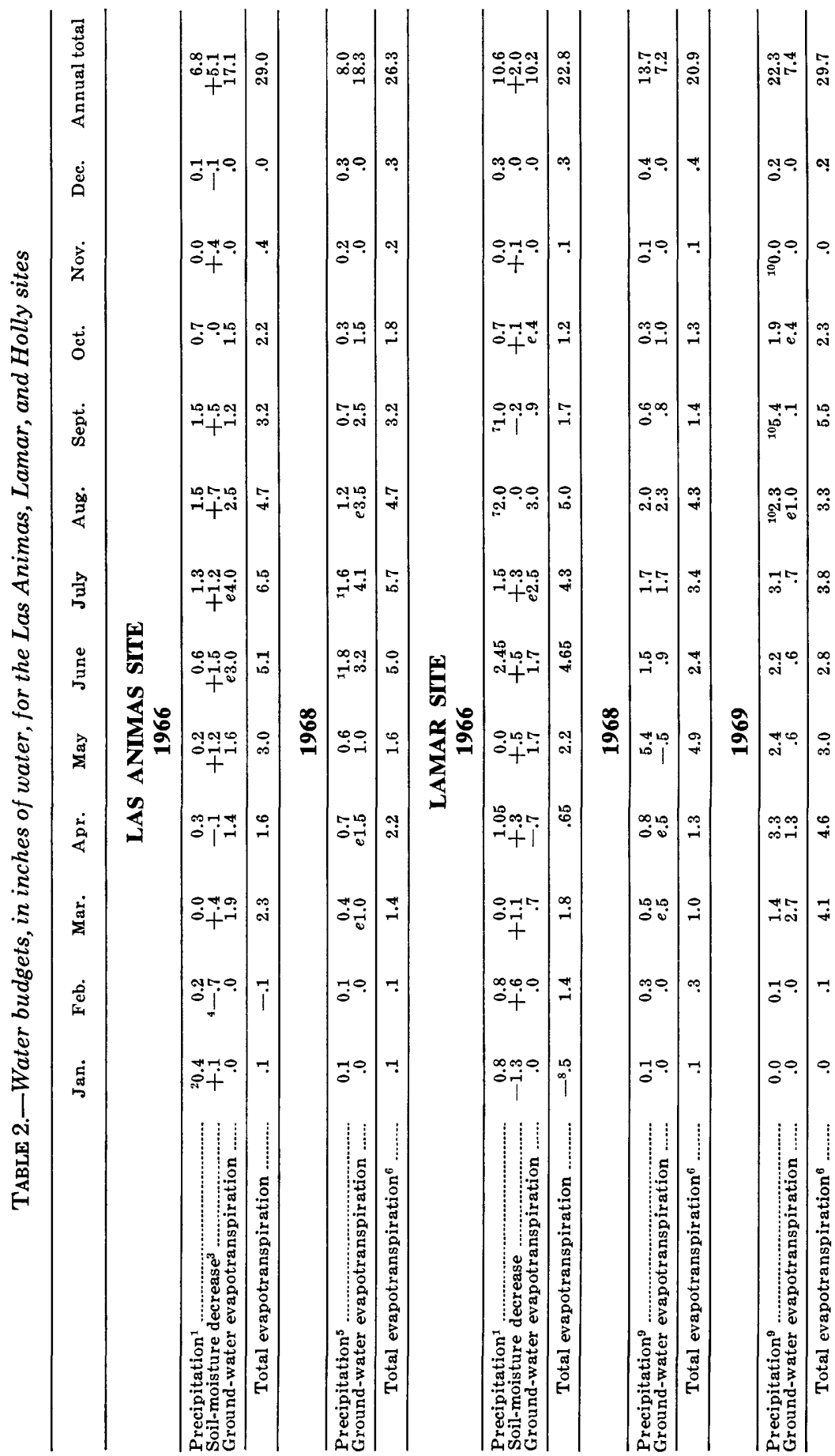




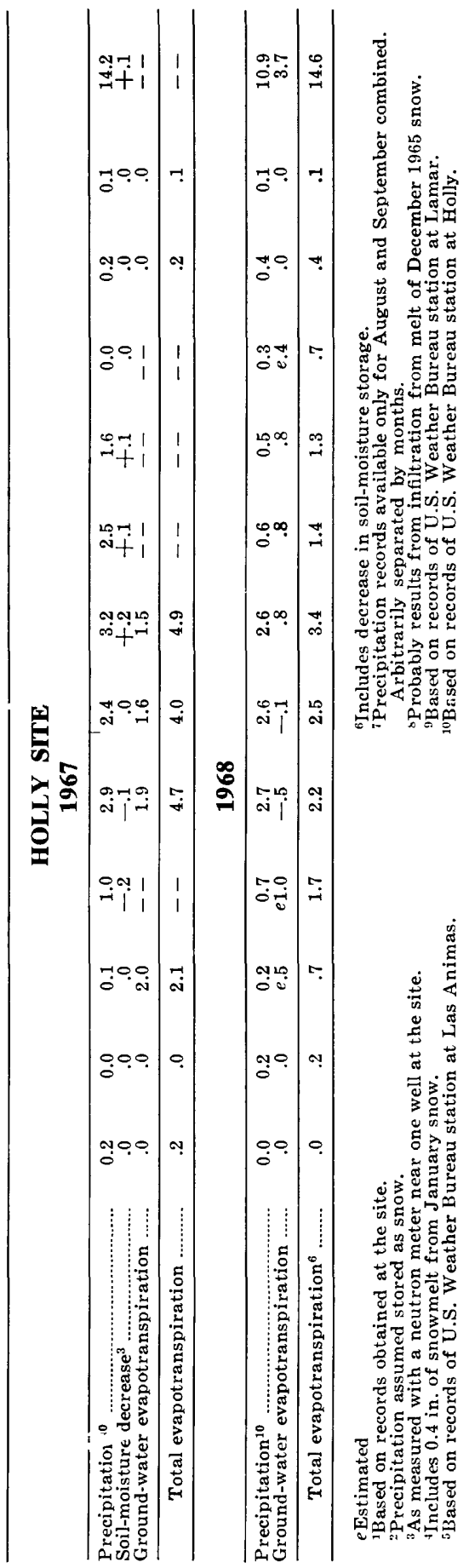




\section{GROUND-WATER EVAPOTRANSPIRATION AND RECHARGE}

For the method tested, evapotranspiration from ground water and recharge are measured together as the average net vertical flux to the ground-water reservoir over the array area. For convenience in describing the theory, this net vertical flux, positive to the aquifer, is termed "accretion." However, in the study area, evapotranspiration from ground water is much greater than recharge and is the main interest of this study. Hence the term "evapotranspiration from ground water" is used in the section summarizing the results of the accretion estimates.

The theory and methodology used to estimate ground-water evapotranspiration follow.

\section{THEORY OF THE FINITE-DIFFERENCE METHOD}

The general approach used to evaluate the ground-water budget for this study (Stallman, 1956) is based on the finite-difference approximation of the differential equation governing ground-water flow. The required data are continuous records of water-level fluctuation in observation wells in a five-point array, as shown in figure $5 \mathrm{~A}$. Water-level altitudes measured simultaneously in the five wells are used to estimate changes in flow through a block having dimensions $a$ on each side. Changes in ground-water storage are estimated from water-level changes with time in well 5 . Accretion to or from the aquifer block is estimated as the difference between the change in through flow and the change in storage.

Three different finite-difference equations were used to analyze water-level data from the various sites. The simplest equation is based on the assumption that the aquifer cross-section may be idealized as shown in figure $5 B$. These and other assumptions necessary for the development of this equation are listed as follows:

1. The aquifer is of uniform thickness.

2. Transmissivity ${ }^{2}$ and specific yield of the aquifer are constant throughout the array.

3. The bedrock surface is horizontal.

4. The aquifer is confined, or, alternatively, changes in water level are small compared to the aquifer thickness.

5. Vertical ground-water flow components within the array are negligible.

6. Accretion, either recharge or discharge, is uniformly distributed over the array.

7. The water-table or potentiometric slope at the midpoint between a corner well and the center well is equal to the head difference between the wells divided by the distance $a$.

\footnotetext{
${ }^{2}$ Transmissivity is the rate at which water of the prevailing kinematic viscosity is transmitted through a unit width of the aquifer under a unit hydraulic gradient.
} 


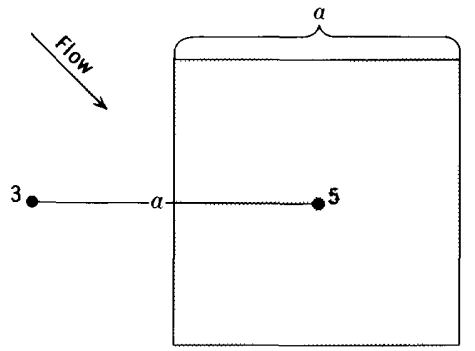

Side 2

Well 2

$A$
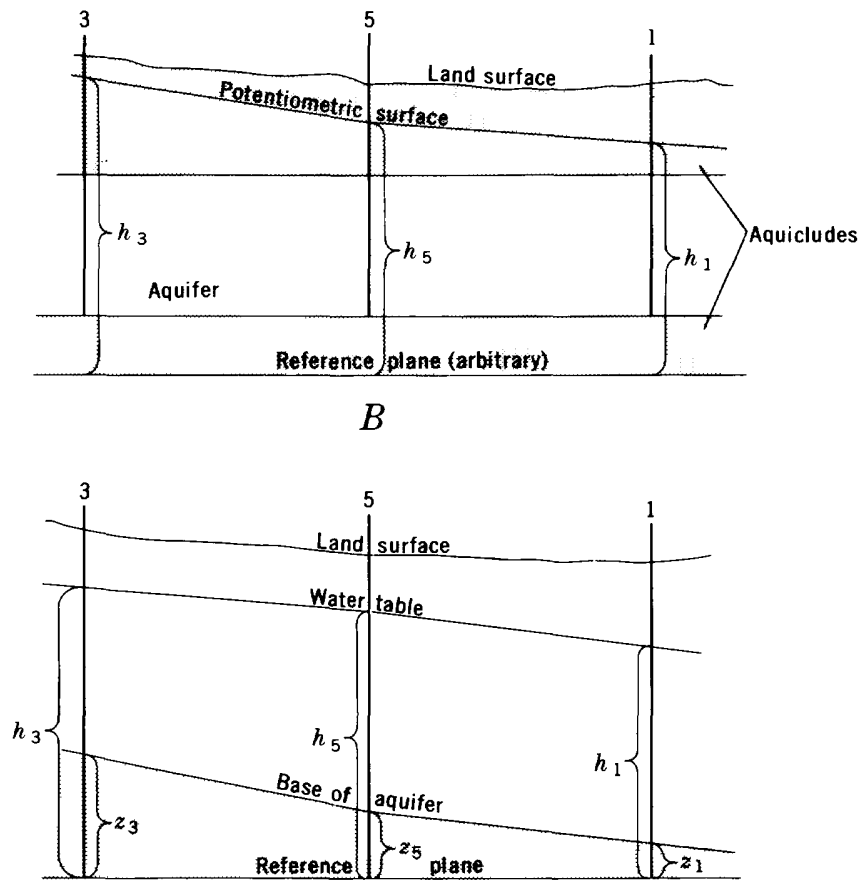

$C$
Area or block for which water budget is determined by the finite-dif-

Side 1 Well 1

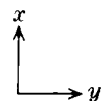
ference method 
8. The average rate of change of head within the aquifer block is equal to that in well 5 .

On the basis of the previous assumption and by assuming flow is in the direction shown by the arrow in figure $5 A$, inflow, $q_{i}$, to the aquifer block of area $a^{2}$ (shaded in fig. $5 A$ ) is given by the equation

or

$$
q_{i}=a T\left[\left(\frac{h_{3}-h_{5}}{a}\right)+\left(\frac{h_{4}-h_{5}}{a}\right)\right]
$$

$$
=T\left(h_{3}+h_{4}-2 h_{5}\right),
$$

where $T=$ transmissivity of the aquifer, in square feet per day, $h_{3}=$ water-level altitude in well 3 (fig. 1), and other $h$ terms are similarly defined.

Similarly, outflow, $q_{o}$, from the shaded aquifer block is $q_{o}=T$ $\left[\left(h_{5}-h_{1}\right)+\left(h_{5}-h_{2}\right)\right]$. Net inflow to the block thus becomes $q_{i}-q_{o}=$ $T\left(h_{1}+h_{2}+h_{3}+h_{4}-4 h_{5}\right)$.

On the basis of the conservation of mass, the net ground-water inflow to the block must be algebraically equal to the inciease in ground-water storage within, and accretion to, the aquifer block. Changes in storage within the block are equal to $a^{2} S\left(\Delta h_{5} / t\right)$, where $a^{2}$ is the area of the block, $\Delta h_{5}$ is the change in head in observation well 5 over the time interval $\Delta t$, and $S$ is the storage coefficient of the aquifer. The volume rate of accretion to the block is approximated by the term $a^{2} W$, where $W$ is the rate of vertical movement of water, termed accretion, to the aquifer. Under these conditions, the finitedifference approximation for the equation of continuity for the aquifer-block becomes

or

$$
T f(h)=a^{2} S \frac{\Delta h}{\Delta t}-a^{2} W
$$

$$
f(h)=\frac{a^{2} S}{T} \frac{\Delta h}{\Delta t}-\frac{a^{2} W}{T},
$$

where $f(h)=h_{1}+h_{2}+h_{3}+h_{4}-4 h_{5}$, and other terms are as previously defined.

For the nonhomogeneous aquifer, the problem is more complicated, because the $f(h)$ term is affected by variations in transmissivity. For example, if the transmissivity from well 5 to well 1 is less than that from well 3 to well 5, a greater decline in head will be necessary from well 5 to well 1 to maintain a given rate of ground-water flow. Head variations thus produced would result in a nonzero value for $f(h)$, even if no accretion or change in storage were occurring. 
If the variation in transmissivity is adequately described as a linear or quadratic function in terms of $x$ and $y$, the term accounting for the effects of variations in transmissivity on the $f(h)$ term can be shown (Stallman, 1963, p. G3) to be

$$
\frac{\left(T_{3}-T_{1}\right) \Delta h_{\mathrm{x}}}{4 T_{5}}+\frac{\left(T_{4}-T_{2}\right) \Delta h_{\mathrm{y}}}{4 T_{5}},
$$

where $T_{3}=$ transmissivity at well 3 , and other $T$ values are similarly defined; $\Delta h_{\mathrm{x}}=\left(h_{3}-h_{1}\right)$ and $\Delta h_{\mathrm{y}}=\left(h_{4}-h_{2}\right)$.

By assuming that

and

$$
\frac{\left(T_{3}-T_{1}\right)}{4 T_{5}}=\mathrm{A}
$$

$$
\frac{\left(T_{4}-T_{2}\right)}{4 T_{5}}=\mathrm{B}
$$

the finite-difference water-budget equation becomes

$$
f(h)+A \Delta h_{x}+B \Delta h_{y}=\frac{a^{2} S}{T} \frac{\Delta h}{\Delta t}-\frac{a^{2} W}{T} .
$$

At the Las Animas and Lamar sites, transmissivity varies with aquifer thickness, and the bedrock surface slopes unevenly over the area of the array. A difference equation describing flow under these conditions, idealized as shown in figure $5 C$, may be developed by assuming that the altitude of the bedrock surface at the midpoint between a corner well and the center well is equal to the average of the altitudes at the two wells and that the hydraulic conductivity ${ }^{3}$ of the aquifer is constant throughout the array. Other assumptions are the same as those listed for equation 1 . Based on these assumptions, the inflow to the block along sides 3 and 4 (fig. $5 \mathrm{~A}$ ) is given, from Darcy's Law, by the equation

$$
\begin{aligned}
q_{i}=a K\left(\frac{\left(h_{3}-z_{3}\right)+\left(h_{5}-z_{5}\right)}{2}\right) & \left(\frac{h_{3}-h_{5}}{a}\right)+ \\
& a K\left(\frac{\left(h_{4}-z_{4}\right)+\left(h_{5}-z_{5}\right)}{2}\right)\left(\frac{h_{4}-h_{5}}{a}\right)
\end{aligned}
$$

or

$$
=\frac{K}{2}\left[h_{3}^{2}+h_{4}^{2}-2 h_{5}^{2}-h_{3}\left(z_{3}+z_{5}\right)-h_{4}\left(z_{4}+z_{5}\right)+h_{5}\left(z_{3}+z_{4}+2 z_{5}\right)\right],
$$

${ }^{3} \mathrm{Hydraulic}$ conductivity is a measure of the ability of the aquifer material to transmit water. The aquifer material will have a hydraulic conductivity of unit length per unit time if it will transmit in unit time a unit volume of water at the prevailing kinematic viscosity through a cross-section of unit area, measured at right angles to the direction of flow, under a hydraulic gradient of unit change in head over unit length of flow path. 
where

$K=$ hydraulic conductivity of the aquifer materials, in feet per day,

$h_{3}=$ water-level height in well 3 above an arbitrary datum, and

$z_{3}=$ height of bedrock surface at well 3 above the same arbitrary datum used to determine $h_{3}$.

Other $h$ and $z$ terms are similarly defined.

Similarly, outflow from the block along sides 1 and 2 is given by the equation

$$
q_{o}=\frac{K}{2}\left[2 h_{5}^{2}-h_{1}^{2}-h_{2}^{2}+h_{1}\left(z_{1}+z_{5}\right)+h_{2}\left(z_{2}+z_{5}\right)-h_{5}\left(z_{1}+z_{2}+2 z_{5}\right)\right] .
$$

Inflow minus outflow becomes

$$
\frac{K}{2}\left[\stackrel{4}{\Sigma}_{i}\left(h_{i}^{2}-h_{i} z_{i}-h_{i} z_{5}+h_{5} z_{i}\right)+4 h_{5} z_{5}-4 h_{5}^{2}\right],
$$

which equals the sum of the increase in storage within and accretion to the aquifer block. Thus, the difference equation becomes

$$
\frac{K}{2}\left[\sum_{i=1}^{+}\left(h_{i}^{2}-h_{i} z_{i}-h_{i} z_{5}+h_{5} z_{i}\right)+4 h_{5} z_{5}-4 h_{5}^{2}\right]=a^{2} S_{y} \frac{\Delta h}{\Delta t}-a^{2} W
$$

or

$$
f(h)=\frac{2 a^{2} S_{y}}{K} \frac{\Delta h}{\Delta t}-\frac{2 a^{2} W}{K},
$$

where $f(h)=$ the bracketed term. For this study, the reference plane was set at the altitude of the bedrock surface at well 5 . Thus, all terms in equation 3 containing $z_{5}$ were eliminated.

\section{REGRESSION ANALYSES OF DORMANT-SEASON WATER-LEVEL DATA}

Water-level data during the period October 16-February 28 were assumed to be unaffected by accretion, because vegetation is dormant and precipitation replenishes soil moisture or is stored as snow. Consequently, for each site, data from this period were analyzed by regression analysis to determine a relationship between $f(h)$ values based on equation 1 or 3 , as appropriate, and $\Delta h / \Delta t$. For the analyses, an $f(h)$ value for a given day was computed by summing midnight water-level altitudes either above an arbitrary datum for equation 1 or above the bedrock surface at well 5 (fig. $5 C$ ) for equation 3 . Values of $\Delta h / \Delta t$ were computed by subtracting (1) the water-level altitude measured in well 5 at midnight of the previous day from (2) the water-level altitude in well 5 at midnight of the following day and (3) dividing by two to obtain the average daily rate of change. The regres- 
sion analysis of all the dormant-season data available for a given site resulted in a correlation equation of the form $f(h)=m(\Delta h / \Delta t)+c$. Here, $m$ is equal to $a^{2} S_{y} / T$ (equation 1 ) or $2 a^{2} S_{y} / K$ (equation 3 ) and the $c$ term includes errors of measurement of the relative altitudes of measuring points of observation wells and other errors associated with the finite-difference approximation of flow through the block.

Additional analyses of the dormant-season data for each site were made by multiple regression analysis of the variables $f(h),\left(h_{3}-h_{1}\right)$, $\left(h_{2}-h_{4}\right)$, and $\Delta h / \Delta t$, on the basis of equation 2 . These analyses yielded coefficients that could be equated to $\Delta T_{x} / 4 T_{5}, \Delta T_{y} / 4 T_{5}$, $a^{2} S_{y} / T_{\overline{5}}$, and $c$.

For the Las Animas and Lamar sites, $f(h)$ values computed by equations 1 and 3 were correlated with the corresponding $\Delta h / \Delta t$ values, and the correlation coefficients compared. Values for $f(h)$ computed by equation 3, which is theoretically more exact than equation 1 , showed higher correlation with $\Delta h / \Delta t$, and the regression equation thus determined was used to estimate ground-water evapotranspiration and hydraulic conductivity at these sites. The regression equations, correlation coefficients, and standard errors of estimate are given in table 3 for the Las Animas and Lamar sites.

TABLE 3.-Regression equations, correlation coefficients, standard errors of estimate, and comparisons of hydraulic conductivity estimates for the Las Animas and Lamar sites

\begin{tabular}{ccccc}
\hline & $\begin{array}{c}\text { Correlation } \\
\text { coefficient }\end{array}$ & $\begin{array}{c}\text { Standard } \\
\text { error of } \\
\text { estimate }\end{array}$ & $\begin{array}{c}\text { Hydraulic } \\
\text { conductivity, } \\
\text { in feet per day } \\
\text { (equation 3) }\end{array}$ & $\begin{array}{c}\text { Hydraulic } \\
\text { conductivity, } \\
\text { in feet per day } \\
\text { (aquifer test) }\end{array}$ \\
\hline $\begin{array}{c}\text { Las Animas: } \\
f(h)=165 \Delta h / \Delta t-3.7 \ldots . .\end{array}$ & 0.65 & 1.3 & 830 & 870 \\
$\begin{array}{c}\text { Lamar: } \\
f(h)=377 \Delta h / \Delta t-10.1 \ldots\end{array}$ & $.7 !$ & 6.4 & 530 & 600 \\
\hline
\end{tabular}

Also shown in table 3 are hydraulic conductivities for the aquifer at the Las Animas and Lamar sites. These values were obtained from the equation $K=2 a^{2} S_{y} / m$, by using the average specific yield value determined by the analysis of neutron moisture logs. The hydraulic conductivities are compared with those determined from published results (Wilson, 1965) for aquifer tests on nearby wells.

The correlation coefficients are fairly low, indicating that only 40-50 percent of the variation in $f(h)$ can be accounted for by variations in $\Delta h / \Delta t$. However, much of the unexplained variation can be accounted for by the roundoff error in individual water-level measurements of about 0.01 foot. Moreover, the good agreement of the hydraulic conductivity values with those computed by other methods suggests that the analysis is valid. Plots of $f(h)$ (as computed from 
equation 3) versus $\Delta h / \Delta t$ for the 150 available data points at the Las Animas site and for the 192 data points at the Lamar site are shown in figures 6 and 7.

Winter water-level data for the Holly site were analyzed by using equation 1. However, the correlation between water-table curvature $[f(h)]$ and changes in water level $(\Delta h / \Delta t)$ for data from the Holly site was so poor that there was nearly a 5 -percent probability that it could have occurred by chance alone. Consequently, the regression equation (2) for a nonhomogeneous aquifer was used to determine a relationship among $f(h), \Delta h / \Delta t, \Delta h_{x}$, and $\Delta h_{y}$ for the winter months. The correlation based on this equation was better, although still poor. The correlation found between $f(h)$ and $\Delta h_{x}$ or $\Delta h_{y}$ probably did not result from variations in transmissivity, because the aquifer thickness at this site, as determined by a seismic survey, is quite uniform. Instead, the correlation may be due to variations in specific yield within the array resulting in effects similar to those caused by variations in transmissivity. The water table at the neutron-logger access tube site is in fine sediments, and the specific yield is only about 0.03 . The water table in other parts of the array might be in coarser materials, and the specific yield larger.

Use of the regression equation based on equation 2 for the entire

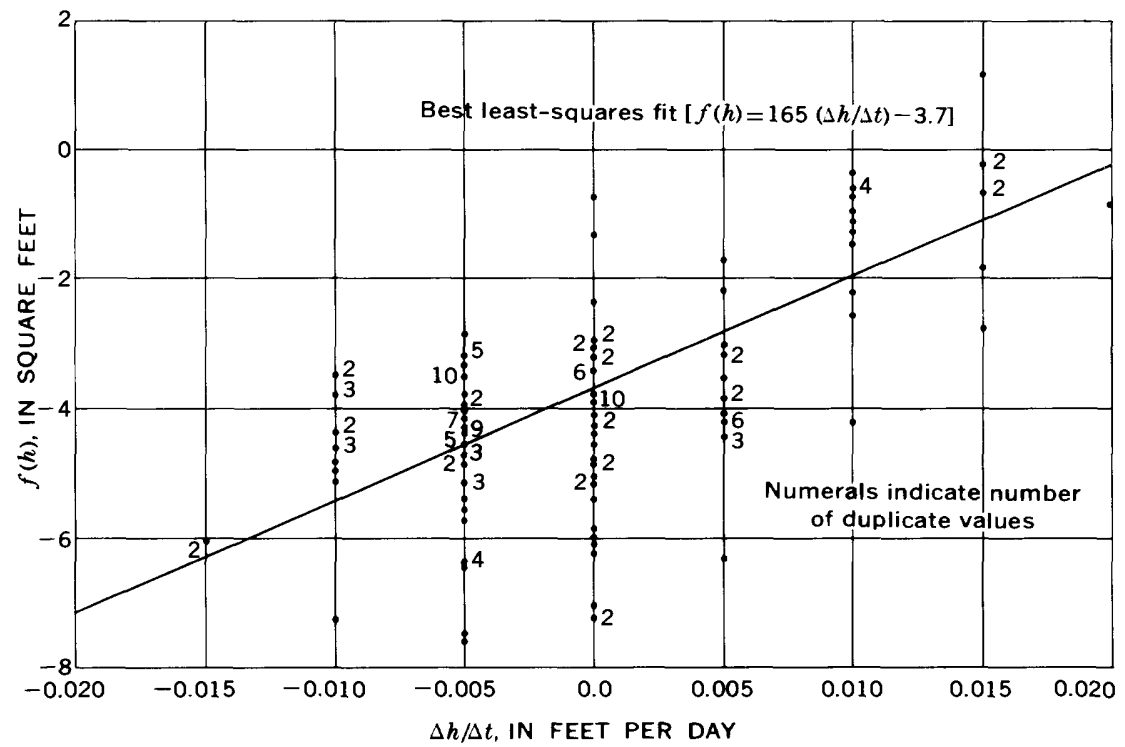

FiguRE 6.-Plot of $f(h)$ versus $\Delta h / \Delta t$ for water-level data obtained at the Las Animas site during the winters of 1966-68 showing the scatter about the leastsquares best fit. 
period of winter record and subsequent computation of accretion using summer data at the Holly site resulted in widely different results in 1967 and in 1968. However, use of separate regression equations for data from the 1966-67 and 1967-68 winters resulted in more consistent estimates of ground-water evapotranspiration for the 2 years. The apparent shift in the relationship may be due to a decline of the water table from fine into coarse materials during the period of record.

The regression equations determined from data at the Holly site for the period of winter record and for the individual winters follows. As can be seen from the results, the regression analyses for the data from the Holly site are questionable. They are included here to show the range of results obtained in the study.

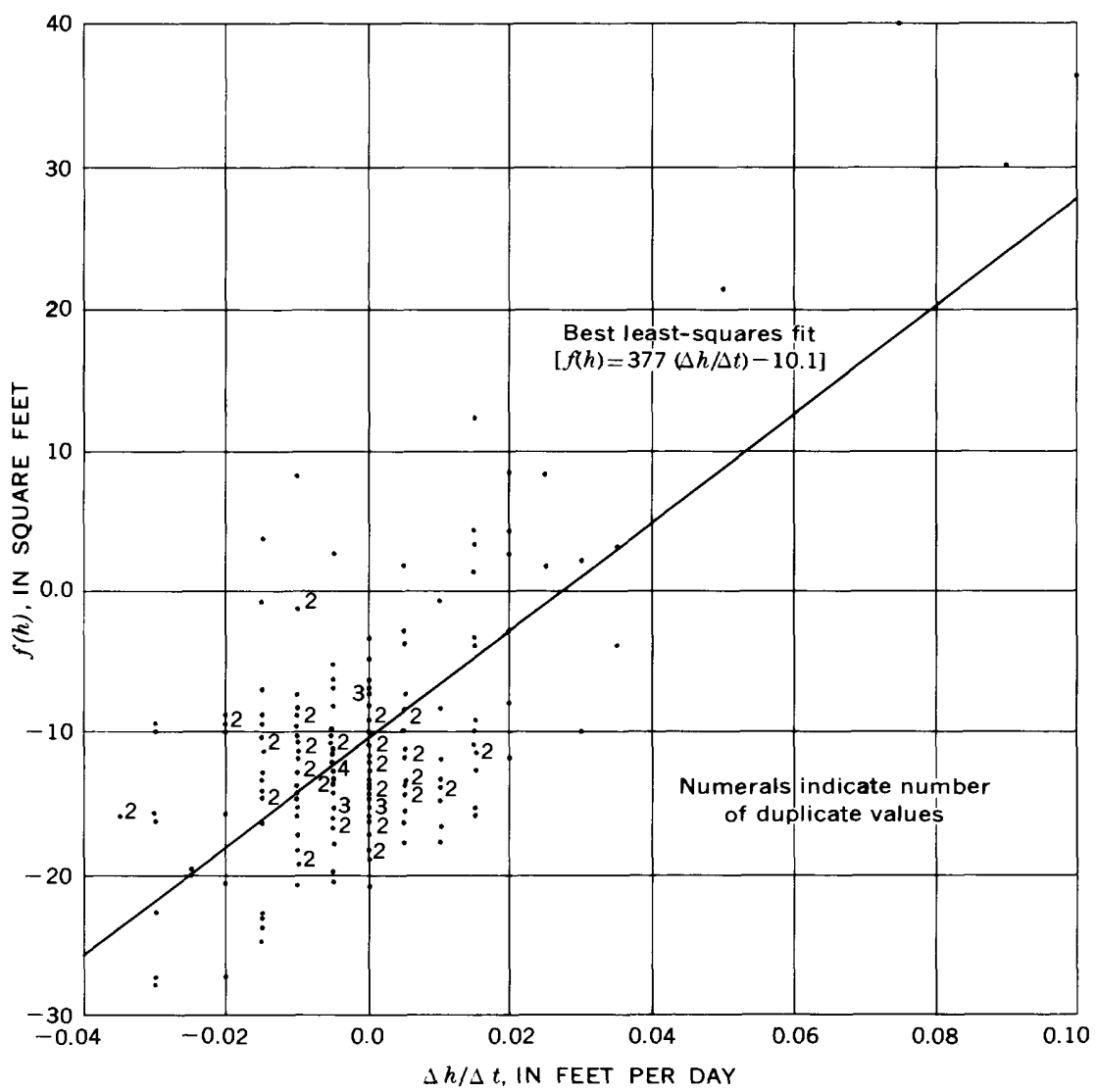

Figure 7.-Plot of $f(h)$ versus $\Delta h / \Delta t$ for water-level data obtained at the Lamar site during the winters of 1966-68 showing the scatter about the least-squares best fit. 


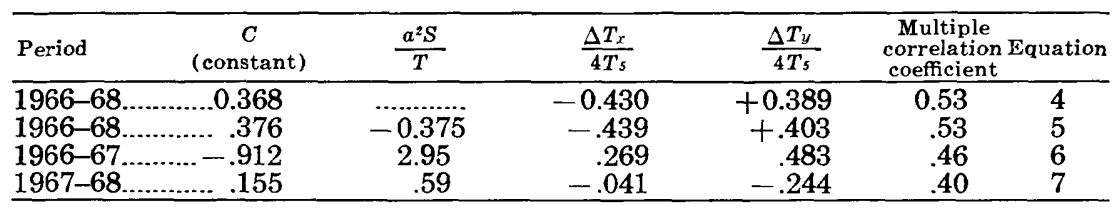

A value for transmissivity at the Holly site could not be obtained from the regression analyses because of the poor correlation and of the uncertainty in specific yield determined for the site. Therefore an estimate for transmissivity based on aquifer tests in the area was used to compute accretion.

Regression analysis of data for the Boone site based on equation 1 yielded a correlation coefficient of only 0.10 , and the multiple regression analysis based on correlation of $f(h)$ with $\Delta h_{x}, \Delta h_{y}$, and $\Delta h / \Delta t$ yielded a multiple correlation coefficient of only 0.31 . Because of the extremely poor correlations determined for this site, no estimates of transmissivity or of evapotranspiration from ground water were made. Poor results at the Boone site probably were obtained because the water table is in very fine materials and the capillary fringe may extend to the surface. Under these conditions, the water table may fluctuate widely in response to small changes in ground-water storage, as described by Childs (1969, p. 264-266).

\section{NET GROUND-WATER EVAPOTRANSPIRATION}

During the growing season, from the first of March through the middle of October, the water-table curvature, $f(h)$, is affected both by evapotranspiration from ground water and by occasional recharge from infiltration of precipitation or snowmelt. Moreover, when both ground-water evapotranspiration and recharge are occurring, only the difference between them will be measured by the finite-difference method. Because evapotranspiration from ground water greatly exceeds recharge in the Arkansas River valley, the accretion term has been equated to net evapotranspiration from ground water, which is equal to total ground-water evapotranspiration minus recharge. Nonetheless, measurement of recharge, when it exceeds evapotranspiration from ground water, is also described.

Finite-difference water-level data for the growing season were analyzed to determine net ground-water evapotranspiration at the Las Animas, Lamar, and Holly sites. These analyses were made by computing daily $f(h)$ values from the midnight water-level readings on the basis of equations 1,2 , or 3 , as appropriate. Also computed were the corresponding $\Delta h / \Delta t$ values, assumed to equal half the change from midnight of the following day to midnight of the previous day, and if equation 2 was used, values for $\left(h_{3}-h_{1}\right)$ and $\left(h_{4}-h_{2}\right)$. 
The water-table curvature $\left[f(h)_{c}\right]$ that would result from the waterlevel change and water slope was computed by use of the regression equation determined from the winter data for that site, and this value subtracted from the $f(h)$ value determined from the measured water levels. The difference between the $f(h)$ value determined from the water levels and that determined from the regression equation was equated to $a^{2} W / T$ or $2 a^{2} W / K$, as appropriate. A $W$ term for each day was computed from the known $a$ and $T$ or $K$ values, and the daily $W$ terms were averaged on a monthly basis.

A comparison of the variation of $f(h)$, as computed by using equation 3, versus $\Delta h / \Delta t$ for the growing season data for the Las Animas site is shown in figure 8 . Also shown is the line representing zero accretion, as computed from the winter data. Points falling above and to the left of the zero-accretion line represent days during which a net loss of ground water occurred, presumably to evapotranspiration. Points below and to the right of the line represent days in which net recharge presumably occurred.

Sufficient records were available from the Las Animas site to compute monthly evapotranspiration from ground water for 5 months in

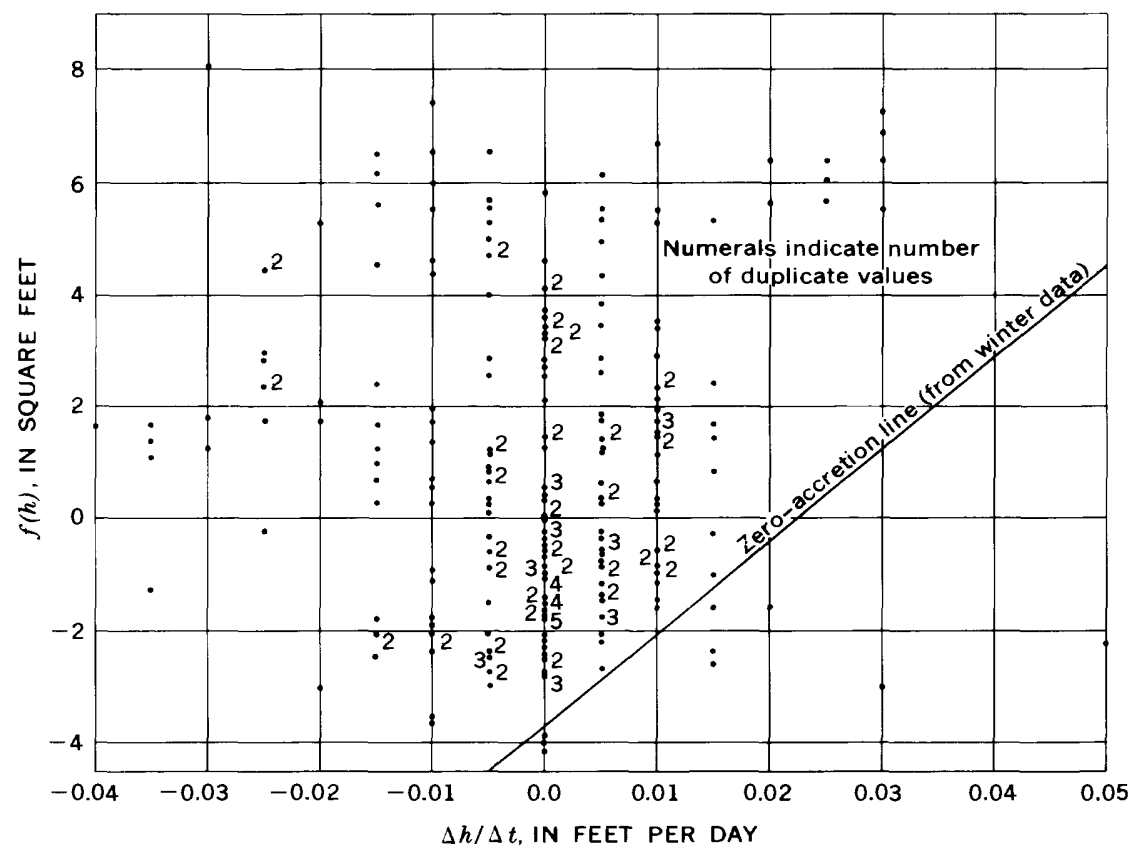

FIGURE 8.-Plot of $f(h)$ versus $\Delta h / \Delta t$ for water-level data obtained at the Las Animas site for the summer seasons of 1966-69 showing the relationship of summer data to the zero-accretion line $(W=0)$ determined from the winter data. 
1966, 1 month in 1967, 5 months in 1968, and 2 months in 1969. Results for 1966 and 1968 are given in table 2. The estimates follow the expected pattern, increasing from March until July and then decreasing until October. Maximum computed evapotranspiration from ground water was 4.1 inches in July 1968.

Most of the data points for the Las Animas site indicate net evapotranspiration of ground water, as would be expected. In fact, net recharge was indicated for a few days in only one month, September 1969. Precipitation was quite high that month, and it is likely that recharge did occur. However, recharge computed by the finite-difference method was improbably high, exceeding precipitation for the month.

Sufficient records were available at the Lamar site to compute evapotranspiration from ground water for 6 months each in 1966, 1968, and 1969 (table 2). Computed evapotranspiration from ground water was much lower than at the Las Animas site, probably because of the lower vegetation density. Monthly ground-water evapotranspiration computed for the Lamar site in 1966 and 1968 increased somewhat unevenly from March until August and then declined. No seasonal pattern was apparent in 1969 , as the values varied unevenly from month to month. Because of the relatively small amounts of evapotranspiration from ground water at the site, monthly values may be substantially in error on a percentage basis.

At the Lamar site, recharge was indicated on many days during the period of record, in part because of the low evapotranspiration rate combined with the rather large scatter inherent in the data on a daily basis. The summer of 1969 was quite wet, however, and recharge may have occurred frequently through the highly permeable soil during that year. The recharge was areally very unevenly distributed, and it is doubtful that the computed recharge rates are accurate. For example, the water level in well 3 (fig. 3 ) rose about 0.3 foot in 2 hours on April 15, 1969, following a 2.1-inch rain, but water levels in other wells rose about 0.25 foot over a 20 -day period. Analysis of data following the sudden rise in well 3 indicated greatly increased inflow not balanced by immediate outflow, resulting in an apparent evapotranspiration rate of about 0.3 inch per day. Data following other heavy rains indicated that recharge did occur, but the computed magnitude was sometimes improbable. From analysis of the 1969 data at the Las Animas and Lamar sites, it appears that recharge in the channeled, uneven floodplain is not areally uniform enough to be accurately computed by the finite-difference method.

Some question existed as to the appropriateness of using midnight water-level data when evapotranspiration is diurnally near its low to make the computations. Consequently, evapotranspiration from 
ground water at the Las Animas and Lamar sites was also computed by using noon water-level data. Evapotranspiration computed from the noon data was about 5 and 3 percent less than that computed from the midnight data at the Las Animas and Lamar sites, respectively. These computations indicate that the water-table curvature term is little affected by diurnal variations in evapotranspiration and responds instead to longer term effects. Consequently, the time of day at which the water-level data are selected for analysis does not appear to be an important consideration for this method.

Records were available to compute evapotranspiration from ground water (table 2) at the Holly site for 4 months in 1967 and 6 months in 1968. Because of an apparent shift in the relationship between $f(h)$ and $\Delta h / \Delta t$, the computations for 1967 were made by using equation 6 , and those for 1968 were made by using equation 7 . The largest monthly value for evapotranspiration of ground water was 2.0 inches in March 1967. In 1968, maximum monthly evapotranspiration from ground water was 0.8 inch in July, August, and September. The values obviously do not follow the expected seasonal pattern.

The results of the computations for the Holly site are questionable because of the poor correlation among $\Delta h / \Delta t$ and $f(h), \Delta h_{r}$ and $\Delta h_{y}$ and because of the unexplained apparent shift in the relationship between 1967 and 1968. A diurnal fluctuation in the water table of as much as 0.05 foot occurs at the site during the summer months. These fluctuations result in minimum water levels in the evening, suggesting that they are due to evapotranspiration from ground water. Thus, the finite-difference method may give qualitatively, if not quantitatively, correct results at the site.

\section{TOTAL EVAPOTRANSPIRATION}

Although the main purpose of this investigation was to evaluate a method for determining evapotranspiration from ground water, estimates of total evapotranspiration at each site were needed for comparison with estimates derived by other methods. Such estimates were made on a monthly basis (table 2 ) by summing, algebraically, net ground-water evapotranspiration, decrease in soil moisture, and precipitation. For the computations, soil-moisture changes were assumed zero for the months they were not available. In addition, annual estimates of evapotranspiration, also shown in table 2, were made for those years for which 5 or more months of ground-water evapotranspiration data were available by estimating values for months of missing record.

Results for the Las Animas site indicate that annual evapotranspiration from ground water was about 18 inches in both 1966 and 1968 and that total evapotranspiration was about 29 inches in 1966 and 
26 inches in 1968 . The lower value for 1968 probably occurred because less soil moisture was available for evapotranspiration. Total and ground-water evapotranspiration computed for the Lamar site were 23 and 10 inches in 1966, 21 and 7 inches in 1968, and 30 and 7 inches in 1969, respectively. The difference in ground-water evapotranspiration in 1966 and 1968 is difficult to explain, because precipitation was nearly the same in each year and more soil moisture, which might be used instead of ground water, was available in 1966 than in 1968. Much of the difference probably arises from the uncertainty of the method. Total evapotranspiration was high in 1969 because of abovenormal precipitation. However, the computed value may be erroneously high because no account was taken of the increase in soil moisture that probably occurred.

Blaney and Criddle (1949) estimated total evapotranspiration of 28 and 35 inches respectively, from "light" and "medium" native vegetation in the Arkansas River valley. Vegetation at the Las Animas site probably should be categorized as "medium," and so the estimates obtained by this investigation are somewhat lower than those of Blaney and Criddle. The total consumptive use at the Lamar site is somewhat less than that of 28 inches listed by Blaney and Criddle for "light native vegetation." This is probably true because the very sparse vegetation at the site (fig. $2 B$ ) may be even less dense than that categorized by Blaney and Criddle as "light."

Reasonably complete annual values for evapotranspiration were obtained for the Holly site in 1968. Total and ground-water evapotranspiration were computed to be about 15 and 4 inches, respectively, in that year. The figure for total evapotranspiration appears to be in the range of values for consumptive use by salt grass shown by Young and Blaney (1942, fig. 5); however, the poor results obtained from the analysis of the winter data at this site indicate that such agreement may be fortuitous.

\section{OTHER WORK}

Urie (1971) used Stallman's (1956) method to estimate effects of strip cutting of jack pine on ground-water recharge to glacial outwash in Michigan. For his analyses, he assumed that the confining clay layer beneath the outwash was horizontal and that the hydraulic conductivity of the outwash was uniform throughout each of four adjoining sites that he tested. He used a finite-difference equation similar to equation 3 in this paper, but with the $z$ terms equal to zero, and weekly water-level data from five-well arrays to compute accretion by the equation $W=\left(K / 2 a^{2}\right) f(h)-S_{u}(\Delta h / \Delta t)$, where the terms are as defined for this paper. He thus ignored any $c$ term in the relationship between $f(h)$ and $S_{\|}$. Urie's estimates of recharge were in 
good agreement with those based on basinwide runoff, and his estimates of the effects of strip cutting of evergreen forest on recharge are in good agreement with those obtained from small watershed studies. (See, for example, Penman, 1963.)

He obtained these excellent results despite the fact that hydraulic conductivity, as determined by the finite-difference analysis during periods of low accretion, varied substantially over the area of his four sites.

His results indicate that recharge may be accurately determined by the proposed method for outwash overlain by sandy soil. However, his results contrast with those for this study, in which recharge was not accurately determined. This difference may be due in part to the fact that recharge was much greater at Urie's sites than at those described in this study, causing errors of a given magnitude to be much smaller on a percentage basis for his study. The opposite results regarding the evaluation of recharge obtained by the two studies indicate that the reliability of the tested method is highly dependent on the topography, geology, soil type, and climate of the area tested.

Urie (1971) also found that the finite-difference method gave erratic results when the water table was very near the surface, tending to confirm our conclusions regarding analysis of data from the Boone site.

\section{SUMMARY AND CONCLUSIONS}

Reasonable estimates of total and ground-water evapotranspiration were obtained at the Las Animas and Lamar sites. Moreover, results from different years for these sites were in good agreement, and the seasonal distribution of computed monthly evapotranspiration generally followed the expected pattern. Finally, analysis of the winter data from these sites provided estimates of hydraulic conductivity in good agreement with those determined from aquifer tests at nearby wells.

The finite-difference method did not give reasonable estimates of recharge from infiltration probably because infiltration is very unevenly distributed within the site, unlike the assumed uniform recharge. Moreover, recharge varies greatly with time, rather than at the assumed constant rate, thus adding to uncertainty of the computed values.

Correlations between $f(h)$ and changes in water level were very poor at the Boone and Holly sites. The water table at these sites was in fine materials overlying the aquifer, and so estimated specific yield values were both very low and likely time-dependent. The capillary fringe at the Boone site extended to land surface when the water table was high, resulting in wide fluctuations in water levels with small 
changes in storage (Childs, 1969, p. 264-266). At the Holly site, the analyses suggested that the water table may be in fine materials in only part of the array, resulting in variation of specific yield in space. Because of these factors, no reliable estimates of hydraulic conductivity nor of evapotranspiration from ground water were obtained.

The results of this study indicate that the finite-difference method may be used to determine evapotranspiration from ground water under suitable conditions. The method is more reliable where the water table lies a few feet below land surface in relatively coarse materials throughout a site. However, even under these conditions, estimates of evapotranspiration from ground water were not accurately determined for the Arkansas River valley sites during periods when recharge from infiltration occurred. Recharge would occur less frequently at sites underlain by fine soil with a large capacity to retain soil moisture than at sites underlain by sandy soil. Thus, for sites at which topography and climate are similar to that in the Arkansas River valley in Colorado, best results would be obtained where the capillary fringe exists in sand and gravel that is overlain by a fine soil with a high moisture-retention capacity, such as at the Las Animas site.

Evapotranspiration from ground water is relatively low in the Arkansas River valley, and the method should provide more reliable estimates in areas where evapotranspiration from ground water is greater, such as the Gila River valley in Arizona (Gatewood and others, 1950) or the Lower Colorado River valley (McDonald and Hughes, 1968) in Arizona and California. Also, on the basis of Urie's (1971) results, the method should provide reliable estimates of ground-water recharge under suitable climatic, topographic, and geologic conditions.

\section{REFERENCES CITED}

Blaney, H. F., and Criddle, W. D., 1949, Consumptive use and irrigation water requirements of crops in Colorado: Report prepared in cooperation with Region 6, U.S. Soil Conserv. Service, Denver, Colo., 55 p.

Childs, E. C., 1969, An introduction to the physical basis of soil water phenomena: New York, John Wiley \& Sons Inc., p. 264-266.

Gatewood, J. S., and others, 1950, Use of water by bottom-land vegetation in lower Safford Valley, Arizona: U.S. Geol. Survey Water-Supply Paper $1103,210 \mathrm{p}$.

McDonald, C. C., and Hughes, G. H., 1968, Studies of consumptive use of water by phreatophytes and hydrophytes near Yuma, Arizona: U.S. Geol. Survey Prof. Paper 486-F, 24 p.

Major, T. J., Hurr, R. T., and Moore, J. E., 1970, Hydrologic data for the lower Arkansas River valley, Colorado: Colorado Conserv. Board Basic Data Release 21, $125 \mathrm{p}$.

Meyer, W. R., 1962, Use of a neutron moisture probe to determine the storage 
coefficient of an unconfined aquifer, in Short papers in geology, hydrology, and topography: U.S. Geol. Survey Prof. Paper 450-E, p. E174-E176.

Penman, H. L., 1963, Vegetation and hydrology: Harpenden Commonwealth Bur. of Soils, Tech. Comm. 53, 124 p.

Stallman, R. W., 1956, Numerical analysis of regional water levels to define aquifer hydrology: Am. Geophys. Union Trans., v. 37, no. 4, p. 451-460.

1963, Calculation of resistance and error in an electric analog of steady flow through nonhomogeneous aquifers: U.S. Geol. Survey Water-Supply Paper 1544-G, $20 \mathrm{p}$.

1967, Flow in the zone of aeration, in Chow, Ven Te, ed., Advances in Hydroscience; v. 4: New York, Academic Press, p. 151-195.

Urie, D. H., 1971, Estimated groundwater yield following strip cutting in pine plantations: Water Resources Research, v. 7, no. 6, p. 1497-1510.

Wilson, W. W., 1965, Pumping tests in Colorado: Colorado Water Conserv. Board Ground Water Circ. 11, 361 p.

Young, A. A., and Blaney, H. F., 1942, Use of water by native vegetation: Calif. Div. of Water Resources Bull. 50, $160 \mathrm{p}$. 